NBER WORKING PAPER SERIES

\title{
SIMULATING ALTERNATIVE SOCIAL SECURITY RESPONSES TO THE \\ DEMOGRAPHIC ITRANSITION
}

\author{
Alan J. Auerbach \\ Laurence J. Kot,likoff
}

Working Paper No. 1308
NATIONAL BUREAU OF ECONOMIC RESEARCH 1050 Massachusetts Avenue
Cambridge, MA 02138
March 1984

\footnotetext{
We thank Andrew Myers for outstanding research assistance. This paper is part of the Brookings Institution project on retirement and aging which is funded by Brookings and the Department of Health and Human Services. The Brookings Institution holds the copyright to this paper. The research reported here is part of the NBER's research program in Taxation and project in Pensions. Any opinions expressed are those of the authors and not those of the National Bureau of Economic Research.
} 
NBER Working Paper \#1308

March 1984

\author{
Simulating Alternative Social Security \\ Responses to the \\ Demographic Transition
}

\begin{abstract}
$\underline{\text { ABSTRACT }}$
The U.S. and other western economies are experiencing dramatic changes in the growth and age structure of their populations. Fluctuations in birth rates are the most important determinants of these changes in the post war period. This paper examines the dynamic effects of baby "booms" and baby "busts" on a range of economic variables using a perfect foresight life cycle simulation model. In addition to describing general transition (as opposed to simply long mul affects of fertility change, the paper considers alternative Social Security policies for avoiding sharp increases in long mun payroll tax rates. These include reductions in benefit replacement rates, advances in Social Security's retirement age, taxation of social security benefits, and the accumulation of a significant Social security trust fund.

According to the simulated demographic transitions, the savings in the U.S. fertility currently underway can have very major impacts on long mun factor returns and produce percipitous short term changes in saving rates. While Social Security policy has important effects on the simulated demographic transitions, these effects are of secondary importance to the long run level of economic welfare. Even if payroll tax rates rise dramatically, long run welfare (measured in terms of levels of adult consumption and leisure) is, nonetheless, substantially higher in the case of a sustained drop in the fertility rate. This reflects, in part, the decline in the number of dependent children per adult; while a sustained decline in the fertility rate eventualiy means a much larger ratio of elderly per capita, the decline in children per capita means an overall decline in the long run ratio of dependents to prime age workers in the economy. A second explanation for the simulated long mun welfare gains is capital deepening associated with lower population growth rates.
\end{abstract}

Alan J. Auerbach

Economics Department

University of Pennsylvania 3718 Locust Walk/CR

Faculty of Arts and Sciences Philadelphia, PA 19104
Laurence J. Kotlikoff

National Bureau of

Economic Research

1050 Massachusetts Avenue Cambridge, MA 02138 


\title{
Simulating Alternative Social Security Responses \\ to the Demographic Transition
}

\author{
by \\ Alan J. Auerbach \\ University of Pennsylvania
}

and

Laurence J. Kotlikoff

Yale University

The 1983 Social Security reform act contains a number of significant changes in the system's current and projected fiscal operations. These include federal income taxation of half of Social Security benefits of high income recipients starting in 1983, gradual increases in the normal retirement age from 65 to 68 starting in 2000, and the expansion of coverage to new government workers and to employees of non-profit organizations. If fully implemented these provisions are projected (under intermediate IIB assumptions) to close Social Security's OASDI, 75 year, open group deficit, with little or no need for additional payroll tax increases beyond those currently stipulated in law.

While the new legislation has greatly allieviated if not eliminated OASDI's short term cash flow problems, the longer term financial picture remains very much in doubt. There are four important reasons for continued concern with and analysis of the system's long term finances. First, even if all aspects of the new law are actually implemented, economic and demographic 
conditions close to the Social Security actuaries' pessimistic assumptions may prevail. In this case the OASDI deficit, expressed as a fraction of taxable payroll, equals 22.7 percent over the period 2020 to 2056 .

The second reason for continued concern about Social Security's long term finances is that most of the long run financial savings from the new legislation arise from measures that are scheduled to be implemented. These measures include increases in the retirement age and the gradual rise, through inflationary bracket creep, in the fraction of Social security recipients whose benefits are taxed under the federal income tax. If future administrations and Congresses periodically legislate away this bracket creep, or if they delay or eliminate raising the retirement age, the nation will again face, under intermediate assumptions, significantly higher OASDI tax rates in the early part of the next century.

The third concern about the new legislation is closely tied to the second. During the period 2000 to 2015 , the ratio of the OASDI trust fund's cummulative projected surplus to annual benefit payments rises from 2.3 to 5.4. To put this figure in perspective, the current ratio of gross U.S. debt to current Social Security benefits is roughly 4.5 . Since the OASDI trust fund holds its reserves in the form of government securities, the 1983 Act implicitly projects Social Security's holding of a significant fraction, if not all, of official government liabilities. While such an OASDI investment policy raises questions of its own, there is the logically prior question of whether future politicians will have the will to preserve a trust fund for future generations that would represent over 5.4 years of benefits by 2015 (7.6 years under the II-A assumptions). Such a surplus is unprecedented in 
the history of the program; the current OASDI reserve can cover less than 3 months of benefit payments. Rather than accumulate a large trust fund, future politicians may dissipate the projected Social Security surplus by legislating larger benefit payments, or by indexing federal income taxation of Social Security benefits, or by reversing the scheduled retirement age increases. Another, more subtle way in which this trust fund could be dissipated involves the government muning larger official deficits over this period because they find the Social Security Trust Fund a ready purchaser of these securities. From the perspective of the government's overall deficit policy, such a program, in the extreme, simply transforms an implicit liability into an explicit liability, and transfers concerns about major increases in payroll tax rates into concerns about major increases in income tax rates. The fourth concern about Social Security's long run finances involves the very sizeable long term Medicare (HI) deficit projected by the Senate Finance Committee. Under current law and using the actuaries' intermediate II-B assumptions, the HI deficit reaches 7.9 percent of taxable payroll by 2030 and rises to 8.3 percent of taxable payroll by 2055 .

The unsettled nature of Social Security's long term finances certainly provides ample rationale for analyzing Social security and the demographic transition. A second motivation for the paper is the rather limited understanding of the general equilibrium effects of demographic change per se on numerous macroeconomic variables, including savings, interest rates, wage rates, and non-Social security tax rates. While the U.S. is engaged in a very aramatic demographic swing, the potential impact of the baby boom's baby bust on general economic performance has received surprisingly little 
attention. The dearth of research in this area probably reflects the difficulty in deriving analytic expressions for the time paths of economies experiencing complex demographic change. This paper addresses the issue using a dynamic life cycle simulation model that simultaneously considers a large variety of economic choices and relationships.

Section II summarizes several key findings of our previous modeling of Social Security that ignored demographics. This discussion is helpful in understanding the contribution of demographic change to the economy's dynamic equilibrium. Section III describes the model's general characteristics and its method of solution. The particular version of the model developed for this analysis has a number of unique features, in particular the inclusion of demographic factors in household saving behavior.

The fourth section presents two different types of demographic transitions for economies both with and without Social Security systems. The two demographic changes considered are: (1) a baby bust involving an immediate and sustained decline in birth rates and (2) a bust-boom-bust cycle of birth rate changes that appears nore closely to resemble the past 60 years of U.S. fertility experience.

Section $V$ examines four different policy alternatives to simply raising Social Security payroll tax rates in response to the Iong term reduction in the fertility rate. These policy options are: (1) reductions in Social Security's replacement rate, (2) increases in Social Security's retirement age, (3) taxation of Social Security benefits under the income tax, and (4) accumulation of a trust fund through general revenue finance, interest on which is used to help finance future Social Security benefit payments. Each 
of these policies constitutes part of the government's current response to Social Security's financial problems.

The simulations presented here, with a more elaborate general equilibrium life cycle model, confirm several general conclusions reached in Auerbach and Kotlikoff (1984). First, demographic changes of the type now projected require very major adjustments in Social Security's finances. Second, while future young generations face a significant burden of supporting parents, they also face a greatly reduced financial burden with respect to child support. On balance, future young workers in the simulation model enjoy higher standards of living than initial young generations under each of the Social Security policy responses considered as well as the response of annually adjusting Social Security payroll taxes to meet pre-specified benefit payments.

The impact of demographic change on the simulated economy's time path of economic variables is quite sizeable. A major baby bust or cycles of baby booms and busts are both capable of producing sharp increases and declines in saving rates long before the demographic transition is complete. In our base case simulation of a baby bust, the economy's saving rate falls by 20 percent in the first year of the transition. It then rises over the next 20 years to a value in excess of that in the initial steady state. By year 50 the saving rate drops to less than two fifths of its initial value. A second general finding concerning demographic transitions is that fertility cycles are capable of producing major economic cycles in wages and interest rates. A third feature of the simulations is that many of the more important changes in economic variables coincide with the appearance in the workforce of baby boom or baby bust generations. 


\section{General Equilibrium Modelling of the Impact of Social Security}

The impact of Social Security on the economy is complicated, because it involves so many aspects of individual behavior. General equilibrium simulation models can be extremely helpful in assessing these effects. In two previous papers we have used such models to evaluate particular effects of an unfunded Social Security system. These models, as well as the one used in the present paper, extend in various ways the basic nodel presented in Auerbach and Kotlikoff (1983a). The basic model consists of three sectors: household, government, and production. Most of the model's complexity lies in its characterization of household decisions as being made, at any time, by 55 overlapping generations of adults, each saving to accumulate resources according to an optimal, life-cycle consumption plan. Household behavior is characterized by perfect foresight; i.e., the future wages, interest rates, and tax rates anticipated by each household at each date are those that actually occur.

In Auerbach and Kotlikoff (1983b) we examined the effect on capital accumulation and welfare of an unfunded Social Security system, by adding such a pay as you go system to the basic simulation model, maintaining the previous assumption of fixed labor supply and retirement ten years before death (i.e., after 45 years of adulthood). We found that Social Security led to a substantial decline in the nation's capital stock and in individual welfare. At the same time, we showed that these significant effects could not be reliably discerned by the use of time series regression models applied to the actual data generated by the simulations themselves.

In Auerbach and Kotlikoff (1984), we extended the basic model in 
several important ways. First, following the techniques developed in Auerbach, et.al. (1983c), we allowed labor supply to be endogenous. This included the retirement decision itself. In addition, we added explicit family structure. Instead of the previous assumption of adults being "born" at age 21 and living for 55 years until age 75, we posited that children spend their first 20 years being supported by adults 20 years older. At age 21 children start their own families. The effect of this change was to include children in each family's consumption decision for that family's first 20 years of existence. Finally, we added a second type of family to those following the pure life cycle model of consumption behavior. This new type, the "infinite horizon altruistic" family, engages in bequest behavior reflecting a concern for the welfare of future generations.

A cost of all these additions was the inability, given the extensive computation requirements, of solving for the model's transition. As a consequence we restricted our analysis of the model to long run steady state effects. Despite its long mun focus, the heterogeneous preference model is sufficiently rich to permit us to answer a number of new questions about the impact of Social Security. Relevant to the current paper was our examination of the effects of a decline in the annual population growth rate from 2 percent to zero. The findings of this analysis include:

(1) With no other structural changes in Social Security, the payroll tax must almost double in response to a population growth rate drop from 2 to zero percent. This tax rate increase is necessary to maintain benefits replacing 60 percent of average monthly earnings. (2) Maintanence of the original payroll tax rate requires an 
increase in the retirement age of between two and three years, a cut in benefits of between one-third and two-fifths, or the accumulation of a trust fund equal to 60 percent of one year's net national product.

(3) Because of the method of Social Security benfit indexing, these effects are unaffected by other changes in the econorn, such as changes in the real wage caused by movements in the capital-labor ratio.

(4) Once children are accounted for, the rise in payroll taxes accompanying a slowdown in population growth need not portend lower lifetime welfare per individual. Since fewer children must be fed by each adult, more resources are made available for the adult's own lifetime consumption. Regardless of the family's time horizon, we found the representative adult living in the zero population growth stead state enjoyed an increase in both consumption and leisure in every year of life when population growth was lower. These last results may or may not hold for generations during the transition to the new steady state. Holding factor prices constant, interim generations with few children, themselves large in number relative to their parents, may be better of $f$ than those in the final steady state because their Social Security tax rates are lower. However, changes in saving and labor supply occuring during the transition alter factor returns, and one cannot infer the welfare of transitional generations from information solely about long run welfare.

The current model, while differing in several respects from that in 
Auerbach and Kotlikoff (1984), permits analysis of the precise demographic transition and, consequently, the precise welfare affects of this transition on particular generations. In order to simulate the demographic transition, we have had to simplify the previous Auerbach-Kotlikoff (1984) model by dropping the assumption of heterogeneous intertemporal preferences and considering only life-cycle families. We hope this restriction can be relaxed in the future, though the solution of the heterogeneous model with fluctuating cohort size assuming perfect foresight is a considerable and apparently very computer-expensive challenge. In the next section we review the version of the Auerbach-Kotlikoff simulation model used in this paper.

\section{The Model and its Solution}

The basic model with variable labor supply is described in detail in Auerbach, et.al. (1983). The inclusion of children and Social Security is described in Auerbach and Kotlikoff (1984). The reader is referred to these papers for the relevant equations describing the behavior of households, firms, the government in general, and the Social Security system in particular. We will summarize these relations briefly before describing how the model is solved and how we have introduced changing fertility rates to the simulations.

Households maximize a lifetime utility function based on the consumption and leisure of adults from age 21 to 75 and their children from the parents' age 21 to 40 . The utility of parent and child is described by a nested, constant elasticity of substitution utility function, with an intertemporal elasticity of substitution (between present and future consumption) 
of .25 and a static elasticity of substitution between current consumption and leisure of .8 . The pure rate of time preference in the function is equal to 1.5 percent. Children's consumption and leisure has a weight that increases over time in their parent's objective function. As the child grows this modeling leads to more consumption. The wage paid to particular age groups follows a profile that rises steeply during childhood, continues to rise less steeply until midale age, and then falis of $\mathrm{f}$ gradualiy. This typically leads to a commencement of part-time work during the late teens and retirement during the late 60s. Households have perfect foresight, in that the relevant future parameters entering into their decisions are those that, in general equilibrium, will actually prevail.

Firms in the model are represented by a single, competitive firm producjng with a constant-returns-to-scale, Cobb-Douglas production function in labor and capital. The capital share in output is set at .25. Aside from Social Security, the government's fiscal policy involves financing a predetermined path of government consumption with a proportional income tax under the constraint of annual budget balance. When population structure changes, we keep constant the level of government consumption expenditures per capita. The Social Security System is financed by a flat rate payroll tax; this tax pays for benefits received after the date of initial benefit receipt based on a formula similar to the one actually used to calculate average indexed monthly earnings (AIME). The model's calculated values of AIME are multiplied by a replacement rate to arrive at the benefit level. Our baseline assumptions are that benefits begin at age 65 and that the replacement rate is 60 percent. Because of their complexity, we ignore the ceiling on the payroll 
tax base (now quite high, anyway), the earnings test that currently prevails between the ages of 65 and 72 , and the early retirement provision available between 62 and 65 . We also assume that the payroll taxes themselves have no work disincentive effects, i.e., are viewed as lump sum taxes by the worker.

The model is solved using a Gauss-Seidel procedure that begins with guesses about aggregate stocks of capital and labor and uses these and the production function to generate wage and interest rates. These factor price paths plus tax rate paths provide time paths of net prices that households use in determining their annual saving and labor supply. Aggregating household saving and labor supply provides new estimates of the economy's capital stock and labor force. Household factor supply, given the government's fiscal constraints, also generates new guesses of the levels of income tax rates, Social Security benefits, and Social Security System payroll tax rates. In each iteration of the model these guesses about tax rates and benefits are incorporated into the households' plans. Hence, when convergence is reached (i.e., the guessed values of variables equal those computed based on these guesses), households have taken account of the tax rates and benefits levels that actually prevail in the perfect foresight equilibrium.

This general method of solution is applied first to the economy's initial steady state, then to the final one to which the econory will converge. Finally, we solve for the years of transition simultaneously, assurning the transition is completed within 250 years. This simultaneous solution is necessary because, with perfect foresight, future variables, such as the interest rate, affect current decisions. We assume that the policy change that led to the disturbance of the initial steady state was unanticipated, but 


\section{$-12-$}

that perfect foresight is immediately reestablished.

Fertility change is introduced into the model in the following way. For a certain period after the beginning of the transition, we exogenously specify the number of births per adult. Thereafter, a procedure is needed to make the population's age structure converge to that of the new steady state. Constancy of the birth rate will not suffice, since the perfect regularity in the birth cycle would perpetuate cohort size differences through an infinite series of "echo effects." In the "real world," this happens to a very much smaller extent because births are distributed over parents of different ages, but such a solution would be infeasible for a simulation model. Instead, we assume that, after a specified period time, typically 50 years, births equal the number born the previous year times the annual population growth rate of the final steady state. The impact of this modeling is that after at most 75 additional years the population age distribution stablizes. This procedure makes the fertility rates themselves endogenous for a period, and they may fluctuate somewhat unrealistically for a time. However, experiments varying the critical date at which fertility rates become endogenous suggest that, as long as it is well after the posited demographic transition has occured, this date has no important influence on the basic nature of the results.

\section{Baseline Simulations: The Economic Effects of a Demographic Transition}

In this section, we present simulation results for two types of demographic transitions: a sudden and permanent reduction in the birth rate (bust) and a cycle of decline and increase in the birth rate followed by a 
permanent drop ("bust-boom-bust"). In the simulations of the bust transition, the fertility rate drops from one involving a 3 percent rate of annual population growth to one yielding a stationary population. In the second set of simulations, containing the "bust-boom-bust" (BBB) fertility behavior, the birth rate drops to one child per parent over a 5 year period. For the next 10 years the rate stays constant, after which it gradually rises reaching its original level twenty years into the transition. Betweeñ years 20 and 35 the birth rate remains at this high value. It then gradually falls again to the zero population growth fertility rate between years 35 and 45 . The birth rate remains at this level until year 50, after which birth rates are endogenously determined according to the requirement that a flat ZPG (zero population growth) age structure is achieved by year 125 and thereafter. The model is given an additional 125 years (a total of 250 years) to reach a new steady state.

In all of our simulations we have had to introduce the assumption of a positive government capital stock to generate plausible values for the economy's capital-output ratio. This was not necessary in our previous life cycle modeling work because of the absence of children. With the consumption needs of nonproductive children added to the population, life cycle behavior based on plausible preference parameters yields extremely small capital stockis. The inability of the life cycle model, by itself, to explain U.S. wealth is a point that has been made by several authors (e.g., Kotlikoff and Summers (1981)). This model provides further indication of the inadequacy of the pure life cycle model without bequests to explain observed rates of capital accumulation. While the current model excludes bequests, the assump- 
tion of a net positive government capital stock yields plausible magnitudes for observed macroeconomic variables. While our modeling of private saving ignores the significant intergenerational transfer behavior that appears to arise in the U.S., it provides an important benchmark for considering such models. In addition, it should be stressed that large masses of U.S. households could have the types of preferences assumed here, but simply hold small or zero amounts of wealth because of the particular shape of their age-wage profile.

We begin our analysis by examining how the composition of the population changes over time for each of these transitions. Table 1 presents the Iraction of the population at different ages during the demographic transition. The top panel presents data for the bust transition, while the bottom panel considers the $\mathrm{BBB}$ transition. In the bust transition the age structure flattens smoothly over time until, in year 50, it is essentially flat, and equal to its long run structure. The Bust-Boom-Bust transition has a more complicated picture, starting out similar to the straight bust, but maintaining through year 50 a fairly steep age structure because of the rebound in the birth rate. The Boom cohort is clearly evident in year $70^{\prime} \mathrm{s}$ bulge in the fraction of young adults between 20 and 40 and, again in year 110 , in the fraction of the population age 61 to 75 . The different time patterns in age structures in these two cases suggest that the BBB transition will take longer to evidence large changes in macroeconomic variables, but will generate larger. swings in these variables as the boom cohort moves through the population. 
Table 1

Population Age Structure in Transition

Bust Transition

$\begin{array}{rrrrr}\text { Year/Cohort } & 1-20 & \underline{21-40} & \underline{41-60} & \frac{61-75}{.07} \\ 0 & .50 & .28 & .15 & .09 \\ 20 & .37 & .36 & .20 & .16 \\ 50 & .28 & .28 & .28 & .20 \\ 70 & .26 & .27 & .27 & .21 \\ 110 & .27 & .27 & .27 & .20 \\ 150 & .27 & .27 & .27 & \end{array}$

Bust-Boom-Bust Transition

$\begin{array}{rrrrr}\text { Year/Cohort } & 1-20 & \underline{20-40} & \underline{40-60} & \frac{61-75}{10} \\ 0 & .50 & .28 & .15 & .07 \\ 20 & .41 & .33 & .18 & .08 \\ 50 & .40 & . & .30 & .19 \\ 70 & .27 & .34 & .26 & .13 \\ 110 & .25 & .25 & .25 & .25 \\ 150 & .27 & .27 & .27 & .20\end{array}$


This intuition is supported by the results of the basic simulations of the economy without Social Security, summarized in Table 2. In these simulations we normalize the initial wage rate to unity and set the government surplus (capital stock) so that the gross interest rate is approximately ten percent. The stock of government capital per capita is held constant throughout each simulation.

In the bust simulation wages rise and interest rates gradually fall throughout the transition reflecting the increase in capital per worker as the fraction of young workers, who own relatively little wealth, decreases. The association of capital deepening with lower population growth rates dates at least from Solow's (1956) growth model with its Keynesian saving behavior. The decline in marginal income tax rates arises because government consumption per capita is held fixed, but the fraction of the population with no taxable income, in this case, children, falls through time. Once the transition has begun, saving rates immediately fall. They then rise through year 20 to a value above that in the initial steady state. There follows a decline in saving rates, which reach negative values in year 110 . Between 110 and 150 the saving rate rises to its ultimate steady state value of zero. The initial drop in the saving rate is unrelated to concurrent demographic changes, which in period one are still unimportant, but to anticipated, general equilibrium increases in future after tax wages. These projected increases in budget opportunities produce higher current consumption and lower current saving. Between years $I$ and 20 the drop in fertility reduces the number of children and the importance of their dissaving, i.e., consumption; by year twenty the frac- 
Table 2

Characteristics of Demographic Transitions

(No Social Security)

Year

0

1

5

10

20

50

70

110

130

150

Year

0

1

5

10

20

50

70

110

130

150

\section{Bust Transition}

Saving

Rate

7.6

6.1

6.6

7.4

$7 \cdot 9$

3.0

$-0.01$

$-1.5$

0

0

\section{Wage}

Rate

1.00

1.00

1.00

1.00

1.02

1.10

1.11

1.11

1.11

1.11

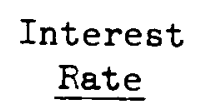

9.9

9.9

10.0

10.0

7.4

$7 \cdot 3$

7.1

7.1

7.1

$7 \cdot 1$

10.6

15.0

13.0

12.4

11.8

11.6

10.6

10.3

10.5

10.6
Marginal

Tax Rate

Bust-Boom-Bust Transition

$\begin{array}{ccc}\text { Saving } & \text { Wage } & \text { Interest } \\ \text { Rate } & \text { Rate } & \text { Rate }\end{array}$

9.9

9.8

9.9

Narginal

Tax Rate

7.6

1.00

1.00

1.00

10.0

15.0

6.2

1.00

1.02

9.3

8.9

8.3

1.06

1.13

6.9

1.11

7.1

14.7

12.7

12.1

14.1

11.8

9.9

10.9

10.7

1.11

7.1

10.6 
tion of the population between 20 and 60 has increased from 45 percent to 56 percent, and this group is doing more saving because of the reduced number of months they must feed. By year 70, however, the decline in birth rates has affected the size of the young and middle age adult saving population, so that the only boom group remaining are the aged dissavers. This leads, temporarily, to a slightly negative saving rate.

The BBB transition as suggested, occurs more slowly and is then characterized by exratic swings in macroeconomic activity as the bulge cohort ages. The wage rate rises gradually to 1.06 by year 70 , rather than the 1.11 of the bust transition. It then overshoots its long mun level as the boom cohort, with its large accumulated savings of capital, retires. Likewise, marginal tax rates take longer to fall and undershoot their long run value. Saving rates remain positive and quite high through year 70 ; they then fall precipitously to -5.0 percent of income in year 110 before converging to zero.

The well-being of individuals alive during either of these transitions can be compared to that of cohorts who die before there is any change in fertility. The method we use is to ask what additional fraction of lifetime resources an individual in the initial steady state would have to receive to be as well off as a member of a particular transition cohort. Normally a well defined measure, this approach has some ambiguity in the current context, because the parent's utility function depends on the consumption and number of children. Our model does not, however, provide reasons for specified changes in fertility. Hence, equating a decline in the number of children with a decline in parental welfare seems rather arbitrary. In a more elaborate model that fully described the fertility decision, a decline in the number of 
children could be associated with both negative and positive changes in parental welfare. For example, if children provide pleasure to their parents, but changes in social customs make childbearing more difficult, this would imply a loss in welfare not present if reduced fertility came about due to, say, an income effect associated with increased living standards. We side-step this problem by focusing on the welfare adults receive directly from their own consumption and leisure. That is, our measure of welfare changes of transition adult cohorts is the increase or decrease in resources (spent on own adult consumption and leisure) that adults in the initial steady state would receive to be left with the level of utility from adult consumption and leisure enjoyed by particular transition cohorts during their adulthoods. This is essentially the equivalent variation measure of the change in economic circumstances faced by a transition cohort.

In Table 8, we express these welfare effects as a percentage of the lifetime resources of initial steady state cohorts. The cohort born in year -75 ( 75 years prior to the date the transition begins) is the last generation not affected by the transition. The first part of the table, labelled "bust," shows the welfare effects of the transition under various fiscal regimes. The first column corresponds to the basic transition without social security discussed above. The drop in birth rates causes a large long run welfare gain of 12.57 percent, about three-fourths of which is realized by those born in year -10 . The primary reason for this upward shift in welfare is the reduction in children per adult. As we are considering welfare measured in terms of adult expenditure on consumption and leisure such a demographic shift permits a higher level of welfare since adults now shift a greater fraction of 
their resources toward their own consumption and leisure. The corresponding BBB transition, represented in the first column of the second part of Table 8 , evidences the same jump in welfare as birth rate declines, but also displays a temporary welfare drop associated with the temporary rise in fertility. We now consider the inclusion of unfunded Social Security in each of these transitions. The baseline model of Social Security assumes a 60 percent replacement rate and an initial age of benefit receipt of 65 . Summary statistics for these simulations are given in Table 3. As expected, saving rates are generally lower and interest rates higher in the presence of social Security. Aside from the payroll tax, the two simulations with Social Security behave rather similarly to their counterparts without Social Security presented in Table 2. The presence of the payroll tax means that, as fertility declines, part of the adult welfare gain previously discussed will be offset by the increased ratio of beneficiaries to workers associated with rising payroll taxes. This is evident if one compares the second column of the two parts of Table 8, corresponding to the welfare effects under the two transitions in the presence of social security. While the qualitative patterns of welfare change are the same, cohorts gain uniformly less. About 45 percent of the long run gain is lost. The effect is smaller in the short run, since the earlier generations escape the burden of higher social security taxes.

Payroll tax rates are quite different in the bust and the bust-boombust transitions. In the first, the number of retirees per worker increases fairly smoothly, with the rise in the payroll tax similarly behaved. In the second, the population bulge represented by the baby boomers holds down 
Table 3

Characteristics of Demographic Transitions

(With Social Security)

Bust Transition

\begin{tabular}{|c|c|c|c|c|c|}
\hline Year & $\begin{array}{l}\text { Savings } \\
\text { Rate }\end{array}$ & $\begin{array}{l}\text { Wage } \\
\text { Rate } \\
\end{array}$ & $\begin{array}{c}\text { Interest } \\
\text { Rate }\end{array}$ & $\begin{array}{l}\text { Marginal } \\
\text { Tax Rate }\end{array}$ & $\begin{array}{l}\text { Payroll } \\
\text { Tax Rate }\end{array}$ \\
\hline 0 & 6.8 & 1.00 & 11.1 & 15.0 & 5.2 \\
\hline 1 & 5.5 & 1.00 & 11.1 & 12.9 & 5.2 \\
\hline 5 & 5.9 & 1.00 & 11.2 & 12.3 & 5.3 \\
\hline 10 & 6.7 & 1.00 & 11.2 & 11.7 & 5.4 \\
\hline 20 & 7.0 & 1.02 & 10.6 & 11.6 & 5.6 \\
\hline 50 & 1.7 & 1.09 & 8.5 & 10.8 & 10.1 \\
\hline 70 & -1.3 & 1.08 & 8.8 & 10.1 & 14.0 \\
\hline 110 & -1.5 & 1.07 & 9.1 & 10.1 & 15.0 \\
\hline 130 & 0 & 1.07 & 9.0 & 10.3 & 13.9 \\
\hline 150 & 0 & 1.07 & 9.0 & 10.3 & 13.9 \\
\hline \multicolumn{6}{|c|}{ Bust-Boom-Bust Transition } \\
\hline Year & $\begin{array}{c}\text { Saving } \\
\text { Rate }\end{array}$ & $\begin{array}{l}\text { Wage } \\
\text { Rate }\end{array}$ & $\begin{array}{c}\text { Interest } \\
\text { Rate }\end{array}$ & $\begin{array}{l}\text { Marginal } \\
\text { Tax Rate }\end{array}$ & $\begin{array}{r}\text { Payroll } \\
\text { Tax Rate } \\
\end{array}$ \\
\hline 0 & 6.8 & 1.00 & 11.1 & 15.0 & 5.2 \\
\hline 1 & 5.5 & 1.00 & 11.0 & 14.7 & $5 \cdot 3$ \\
\hline 5 & 5.9 & 1.00 & 11.2 & 12.6 & 5.2 \\
\hline 10 & 6.8 & 1.00 & 11.2 & 12.0 & 5.3 \\
\hline 20 & 7.8 & 1.02 & 10.5 & 14.1 & 5.5 \\
\hline 50 & 3.6 & 1.03 & 10.1 & 11.8 & 7.5 \\
\hline 70 & 5.1 & 1.05 & 9.6 & 9.9 & 8.6 \\
\hline 110 & -5.6 & 1.08 & 8.7 & 10.5 & 18.7 \\
\hline 130 & 0 & 1.07 & 9.1 & 10.3 & 13.8 \\
\hline 150 & 0 & 1.07 & 9.0 & 10.3 & 13.9 \\
\hline
\end{tabular}


payroll tax increases while they are working, and causes them to jump sharply once this cohort retires. In year 110 the payroll tax rate is 18.7 percent, almost 3.5 times the initial steady state value.

V. Social Security Policy Responses to the Demographic Transition

Table 4 shows saving, wage, interest, and tax rates arising under the two demographic transitions if Social Security's replacement rate is cut in year zero from 60 to 40 percent. These benefit cuts apply to all cohorts receiving benefits at the time they are implemented. The table also presents comparable figures for a gradual reduction in the replacement rate to 40 percent starting in year zero and ending in year 20. Table 3 indicates the time paths of these variables when the replacement rate is held fixed. A quick comparison of these two tables indicates that the Social Security tax rate is quite sensitive to the benefit cut policy, while the impact on other variables is relatively minor. Rather than rising to 13.9 percent, as in Table 3 , the long mun Social Security tax rate in Table 4 increases from 5.2 percent to 9.2 percent. The Social Security tax rate is significantly lower throughout the transition under the policy of immediately cutting the replacement rate than in the transitions of Table 3.

The benefit cuts, by reducing the scale of unfunded Social Security, generates a 3 percent larger pre-tax wage rate than would otherwise occur. The additional capital deepening associated with this larger long man wage rate explains the slightly larger saving rates in Table 4 compared with those of Table 3. The affect of phasing in the replacement rate cut rather than implementing it immediately is to leave the economy with roughly 20 percent higher payroll tax rate rates during the first ten years of the tran- 
Table 4

Immediate Cut in Replacement Rate from $60 \%$ to $40 \%$

Year

0

1
5

10

20

50

70

100

110

130

150
Baby Bust

$\begin{array}{rrrrr}\underline{S} / \underline{Y} & \underline{\mathbf{w}} & \underline{\underline{r}} & \underline{\mathrm{y}} & \underline{\tau S S} \\ 6.8 & 1.00 & 11.1 & 15.0 & 5.2 \\ 6.6 & 1.00 & 11.2 & 12.7 & 3.5 \\ 6.8 & 1.00 & 11.1 & 12.3 & 3.5 \\ 7.2 & 1.01 & 10.9 & 11.9 & 3.6 \\ 7.3 & 1.03 & 10.2 & 11.8 & 3.8 \\ 3.0 & 1.12 & 10.2 & 10.9 & 6.7 \\ -1.1 & 1.11 & 8.0 & 10.4 & 9.4 \\ -.3 & 1.11 & 8.2 & 10.9 & 9.4 \\ -1.5 & 1.10 & 8.2 & 10.5 & 10.0 \\ .0 & 1.10 & 8.4 & 10.6 & 9.2 \\ .0 & 1.10 & 8.4 & 10.6 & 9.2\end{array}$

Bust-Boom-Bust

$\underline{S / Y} \quad \underline{\mathrm{y}} \quad \underline{\mathrm{y}} \quad \underline{\tau S S}$

$\begin{array}{lllll}6.8 & 1.00 & 11.1 & 15.0 & 5.2\end{array}$

$\begin{array}{lllll}6.7 & 1.00 & 11.1 & 14.5 & 3.5\end{array}$

$\begin{array}{lllll}6.8 & 1.00 & 11.1 & 12.6 & 3.5\end{array}$

$\begin{array}{lllll}7.4 & 1.01 & 10.9 & 12.1 & 3.5\end{array}$

$\begin{array}{lllll}8.1 & 1.03 & 10.5 & 14.3 & 3.7\end{array}$

$\begin{array}{lllll}4.5 & 1.05 & 9.6 & 12.0 & 5.0\end{array}$

$\begin{array}{lllll}5.4 & 1.06 & 9.2 & 10.1 & 5.8\end{array}$

$\begin{array}{lllll}-1.4 & 1.17 & 7.7 & 11.2 & 8.9\end{array}$

$\begin{array}{lllll}-5.5 & 1.11 & 8.1 & 10.9 & 12.5\end{array}$

$\begin{array}{lllll}-.1 & 1.10 & 8.4 & 10.7 & 9.2\end{array}$

Gradual (20 Year) Cut in Replacement Rate from 60\% to 40\%

Baby Bust

$\begin{array}{crrrrr}\text { Year } & \underline{S} / \underline{Y} & \underline{\mathbf{w}} & \underline{\mathbf{r}} & \underline{\boldsymbol{y}} & \underline{\tau} S \\ 0 & 6.8 & 1.00 & 11.1 & 15.0 & 5.2 \\ 1 & 6.2 & 1.00 & 11.2 & 12.8 & 4.7 \\ 5 & 6.6 & 1.00 & 11.2 & 12.3 & 4.4 \\ 10 & 7.2 & 1.03 & 11.0 & 11.8 & 4.0 \\ 20 & 7.4 & 1.11 & 10.2 & 11.8 & 3.8 \\ 50 & 2.7 & 1.11 & 8.0 & 10.9 & 6.8 \\ 70 & -1.1 & 1.11 & 8.2 & 10.4 & 9.4 \\ 100 & -.3 & 1.11 & 8.2 & 10.9 & 9.4 \\ 110 & -1.5 & 1.10 & 8.4 & 10.5 & 10.0 \\ 130 & .0 & 1.10 & 8.4 & 10.6 & 9.2 \\ 150 & .0 & 1.10 & 8.4 & 10.6 & 9.2\end{array}$

Bust-Boom-Bust

\begin{tabular}{rrrrr}
$\underline{S} / \underline{Y}$ & $\underline{w}$ & $\underline{\mathbf{r}}$ & \multicolumn{1}{c}{$\boldsymbol{y}$} & $\underline{\tau S S}$ \\
6.8 & 1.00 & 11.1 & 15.0 & 5.2 \\
6.3 & 1.00 & 11.1 & 14.5 & 4.7 \\
6.6 & 1.00 & 11.2 & 12.6 & 4.3 \\
7.4 & 1.00 & 11.0 & 12.1 & 3.9 \\
8.2 & 1.03 & 10.2 & 14.3 & 3.7 \\
4.3 & 1.05 & 9.7 & 12.0 & 5.0 \\
5.4 & 1.06 & 9.2 & 10.1 & 5.8 \\
-1.4 & 1.13 & 7.7 & 11.2 & 8.9 \\
-.1 & 1.11 & 8.1 & 10.9 & 12.5 \\
.1 & 1.10 & 8.4 & 10.7 & 9.2 \\
0 & 1.10 & 8.4 & 10.6 & 9.2
\end{tabular}


sition. The welfare effects of these benefit cuts are predictable. For both demographic transitions, the immediate cut in benefits causes a welfare loss to older generations alive in year zero (Table 8), but a welfare improvement for younger cohorts, even for those who are age twenty-five, and hence al ready working, at the time of the change. In the long mun, such a policy leads to substantially greater welfare then under the policy of simply passively adjusting social security tax rates to meet the benefits associated with a 60 percent replacement rate.

An alternative to the explicit reduction in benefit levels would be an increase in the retirement age. Table 5 presents the characteristics of the demographic transition for two such policies, an immediate increase in the retirement age from 65 to 67 , and the same rise occuring in year 20 , after being announced in year zero. The welfare effects of the first of these policies is shown in the fifth column of Table 8. Both in terms of macroeconomic and welfare effects, an immediate increase in the retirement age by two years has a similar but smaller impact than the immediate 40 percent benefit cut. In the long run, the payroll tax rate rises to 11.0 percent, higher than the 9.2 percent in the former case. Likewise, the long mun welfare gain of 8.94 percent is smaller than the previous gain of 10.21 percent. If one extrapolates from our results, they suggest that maintenance of the original payroll tax rate would require a benefit cut of close to 75 percent, and/or an increase in the retirement age by 6 years.

Another alternative that has been suggested to reduce the growth in payroll taxes is the taxation of social security benefits. Indeed, starting with the Tax Equity and Fiscal Responsibility Act of 1982, higher income fami- 
Table 5

Immediate Increase in Retirement Age from 65 to 67

Baby Bust

Year
0
1
5
10
20
50
70
100
110
130
150

Gradual Increase in Retirement Age from 65 to 67 Baby Bust

$\begin{array}{rrrrr}6.8 & 1.00 & 11.1 & 15.0 & 5.2 \\ 5.9 & 1.00 & 11.2 & 12.8 & 5.2 \\ 6.4 & 1.00 & 11.2 & 13.3 & 4.2 \\ 7.0 & 1.00 & 11.1 & 11.8 & 4.1 \\ 7.3 & 1.02 & 10.3 & 11.7 & 4.3 \\ 2.4 & 1.11 & 8.2 & 10.9 & 7.7 \\ -1.2 & 1.10 & 8.4 & 10.3 & 11.6 \\ -.4 & 1.10 & 8.4 & 10.8 & 10.9 \\ -1.5 & 1.08 & 8.7 & 10.3 & 12.3 \\ 0 & 1.09 & 8.6 & 10.5 & 11.0 \\ 0 & 1.09 & 8.6 & 10.5 & 11.0\end{array}$

Bust-Boom-Bust

$\begin{array}{rrrrr}\underline{S} / Y & \underline{\mathbf{w}} & \underline{\mathbf{r}} & \underline{\mathbf{y}} & \underline{\tau S S} \\ 6.8 & 1.00 & 11.1 & 15.0 & 5.2 \\ 6.0 & 1.00 & 11.1 & 14.6 & 5.2 \\ 6.3 & 1.00 & 11.2 & 12.6 & 4.1 \\ 7.2 & 1.00 & 11.1 & 12.0 & 4.1 \\ 8.0 & 1.03 & 10.3 & 14.3 & 4.2 \\ 4.1 & 1.04 & 9.8 & 11.9 & 5.8 \\ 5.3 & 1.06 & 9.4 & 10.0 & 7.2 \\ -1.5 & 1.12 & 7.8 & 11.1 & 10.1 \\ -5.6 & 1.10 & 8.3 & 10.7 & 15.9 \\ .1 & 1.09 & 8.7 & 10.5 & 11.1 \\ 0 & 1.09 & 8.6 & 10.6 & 11.0\end{array}$

Bust-Boom-Bust

Year

0
1
5
10
20
50
70
100
110
130
150

$\underline{S / Y} \quad \underline{\mathrm{r}} \underline{\mathrm{r}} \underline{\mathrm{t}} \underline{\underline{\mathrm{S} S}}$

$\begin{array}{lllll}6.8 & 1.00 & 11.1 & 15.0 & 5.2\end{array}$

$\begin{array}{lllll}5.6 & 1.00 & 11.1 & 12.9 & 5.2\end{array}$

$\begin{array}{lllll}6.1 & 1.00 & 11.2 & 12.3 & 5.3\end{array}$

$\begin{array}{lllll}6.8 & 1.00 & 11.1 & 11.8 & 5.3\end{array}$

$\begin{array}{lllll}7.3 & 1.02 & 10.5 & 11.6 & 5.0\end{array}$

$\begin{array}{rrrrr}2.1 & 1.10 & 8.2 & 11.9 & 7.9\end{array}$

$\begin{array}{lllll}-0.2 & 1.10 & 8.4 & 10.3 & 11.6\end{array}$

$\begin{array}{lllll}-0.3 & 1.10 & 8.4 & 10.8 & 10.9\end{array}$

$\begin{array}{lllll}-1.5 & 1.08 & 8.7 & 10.3 & 12.3\end{array}$

$\begin{array}{lllll}0.0 & 1.09 & 8.6 & 10.5 & 11.0\end{array}$

$\begin{array}{lllll}0.0 & 1.09 & 8.6 & 10.5 & 11.0\end{array}$
$\underline{S / Y} \quad \underline{\mathrm{w}} \quad \underline{\underline{\mathrm{r}}} \underline{\mathrm{TSS}}$

$\begin{array}{lllll}6.8 & 1.00 & 11.2 & 15.0 & 5.2\end{array}$

$\begin{array}{lllll}5.7 & 1.00 & 11.0 & 14.6 & 5.2\end{array}$

$\begin{array}{lllll}6.1 & 1.00 & 11.2 & 12.6 & 5.2\end{array}$

$\begin{array}{lllll}7.0 & 1.00 & 11.1 & 12.0 & 5.3\end{array}$

$\begin{array}{lllll}8.0 & 1.02 & 10.4 & 14.2 & 4.9\end{array}$

$\begin{array}{lllll}3.8 & 1.04 & 9.9 & 11.9 & 5.8\end{array}$

$\begin{array}{lllll}5.3 & 1.06 & 9.4 & 10.0 & 7.2\end{array}$

$\begin{array}{lllll}-1.5 & 1.12 & 7.8 & 11.1 & 10.1\end{array}$

$\begin{array}{lllll}-5.6 & 1.10 & 8.3 & 10.8 & 15.9\end{array}$

$\begin{array}{lllll}1.2 & 1.09 & 8.7 & 10.5 & 11.0\end{array}$ 
$-26-$

Table 6

Immediate Taxation of Social Security Benefits

Baby Bust

Year

0

1

5

10

20

50

70

100

110

130

150

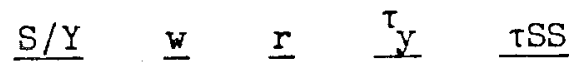

$\begin{array}{lllll}6.8 & 1.00 & 11.1 & 15.0 & 6.0\end{array}$

$\begin{array}{lllll}5.8 & 1.00 & 11.1 & 12.8 & 4.5\end{array}$

$\begin{array}{lllll}6.2 & 1.00 & 11.2 & 12.3 & 4.6\end{array}$

$\begin{array}{lllll}6.8 & 1.00 & 11.1 & 11.8 & 4.7\end{array}$

$\begin{array}{lllll}7.1 & 1.02 & 10.4 & 11.7 & 5.0\end{array}$

$\begin{array}{lllll}2.2 & 1.10 & 8.3 & 10.9 & 9.0\end{array}$

$\begin{array}{lllll}-1.3 & 1.09 & 8.6 & 10.2 & 12.6\end{array}$

$\begin{array}{lllll}-0.4 & 1.09 & 8.6 & 10.7 & 12.6\end{array}$

$\begin{array}{lllll}-1.5 & 1.08 & 8.9 & 10.2 & 13.5\end{array}$

$\begin{array}{lllll}0.0 & 1.08 & 8.8 & 10.4 & 12.5\end{array}$

$\begin{array}{lllll}0.0 & 1.08 & 8.8 & 10.4 & 12.5\end{array}$
Bust-Boor-Bust

$\underline{S / Y} \quad \underline{\underline{r}} \underline{\underline{y}} \underline{\mathrm{TSS}}$

$\begin{array}{llllll}6.8 & 1.00 & 11.1 & 15.0 & 6.0\end{array}$

$\begin{array}{lllll}6.0 & 1.00 & 11.1 & 14.6 & 4.5\end{array}$

$\begin{array}{lllll}6.2 & 1.00 & 11.2 & 12.6 & 4.6\end{array}$

$\begin{array}{lllll}7.0 & 1.00 & 11.1 & 12.1 & 4.7\end{array}$

$\begin{array}{lllll}7.9 & 1.02 & 10.4 & 14.2 & 4.7\end{array}$

$\begin{array}{lllll}3.9 & 1.04 & 9.9 & 11.9 & 6.6\end{array}$

$\begin{array}{lllll}5.2 & 1.05 & 9.5 & 9.9 & 7.8\end{array}$

$\begin{array}{lllll}-1.6 & 1.12 & 8.0 & 11.0 & 11.8\end{array}$

$\begin{array}{lllll}-5.6 & 1.09 & 8.5 & 10.7 & 16.7\end{array}$

$\begin{array}{lllll}0.1 & 1.08 & 8.9 & 10.4 & 12.4\end{array}$

$\begin{array}{lllll}0.0 & 1.08 & 8.8 & 10.5 & 12.5\end{array}$ 
lies will face regular income taxation on half their social security benefits. In Table 6, and the last column of Table 8, we show the effects of taxing all social security benefits beginning at the start of the demographic transition, with the receipts kept within the social security system to reduce payroll taxes. Such a policy leads initially to reductions in social security taxes, but in the long run has a smaller impact than any of the policies previously examined, because of the relatively low rate of income taxation. Ass this suggests, the long run welfare impact of this policy is smaller than the others, but generations reaching adulthood early in the transition actually do almost as well as under the other policies.

Finally, we consider in Table 7 a policy that sorne have advocated as a long run solution to the long run social security deficit: the accumulation of a trust fund. The simulated policy involves a one-third surcharge on the payroll tax for the first twenty years of the transition, proceeds of which are contributed to the trust fund, i.e.; in the initial twenty year period this policy raises revenues by one-third more than is necessary, in equilibrium, to pay for current benefits. After year twenty the accumulated trust fund is held constant per capita, and the income and principal beyond that needed to maintain a constant per capita trust fund is used to help pay for benefits. Under this policy the social security tax rate drops to essentially zero in year 20 of both transitions and, as the retiree/worker ratio rises, significantly limits the rise in the payroll tax. In each simulation, the long run payroll tax $(8.4$ percent for the bust case, 8.8 percent for the BBB case) is the lowest of any of the simulations presented. As one would expect, the trust fund transitions produce the highest long run welfare gains of any of the social security tran- 
Table 7

Accumulation of a Social Security Trust Fund

Baby Bust

Year

0

1

5

10

20

50

70

100

110

130

150
$\underline{S / Y} \quad \underline{\mathrm{w}} \quad \underline{\mathrm{r}} \quad \underline{\mathrm{y}} \quad \underline{\mathrm{TSS}}$

$\begin{array}{lllll}6.8 & 1.00 & 11.1 & 15.0 & 6.0\end{array}$

$\begin{array}{lllll}5.9 & 1.00 & 11.2 & 12.8 & 7.0\end{array}$

$\begin{array}{lllll}6.4 & 1.00 & 11.2 & 12.4 & 7.0\end{array}$

$\begin{array}{lllll}7.2 & 1.00 & 11.1 & 12.0 & 7.1\end{array}$

$\begin{array}{lllll}7.5 & 1.03 & 10.2 & 12.5 & -0.0\end{array}$

$\begin{array}{lllll}2.1 & 1.11 & 8.0 & 11.4 & 5.3\end{array}$

$\begin{array}{lllll}-1.4 & 1.11 & 8.1 & 10.9 & 8.3\end{array}$

$\begin{array}{lllll}-0.0 & 1.11 & 8.1 & 11.4 & 8.8\end{array}$

$\begin{array}{lllll}-1.5 & 1.10 & 8.3 & 11.0 & 9.2\end{array}$

$\begin{array}{lllll}0.0 & 1.10 & 8.3 & 11.2 & 8.4\end{array}$

$\begin{array}{lllll}0.0 & 1.10 & 8.3 & 11.2 & 8.4\end{array}$
Bust-Booz-Bust

$\underline{S / Y} \quad \underline{\underline{r}} \underline{\underline{\mathrm{y}}} \underline{\mathrm{\tau SS}}$

$\begin{array}{lllll}6.8 & 1.00 & 11.1 & 15.0 & 6.0\end{array}$

$\begin{array}{lllll}6.0 & 1.00 & 11.1 & 14.6 & 7.0\end{array}$

$\begin{array}{lllll}6.4 & 1.00 & 11.2 & 12.7 & 7.0\end{array}$

$\begin{array}{lllll}7.5 & 1.00 & 11.1 & 12.3 & 7.1\end{array}$

$\begin{array}{lllll}8.5 & 1.03 & 10.1 & 15.2 & 0.9\end{array}$

$\begin{array}{lllll}3.4 & 1.05 & 9.5 & 12.9 & 1.8\end{array}$

$\begin{array}{llllll}5.3 & 1.07 & 9.0 & 10.7 & 3.6\end{array}$

$\begin{array}{lllll}-1.6 & 1.13 & 7.6 & 11.7 & 8.7\end{array}$

$\begin{array}{lllll}-5.6 & 1.11 & 8.1 & 11.4 & 13.2\end{array}$

$\begin{array}{lllll}0.2 & 1.10 & 8.4 & 11.2 & 8.6\end{array}$

$\begin{array}{lllll}0.1 & 1.10 & 8.3 & 11.2 & 8.8\end{array}$ 


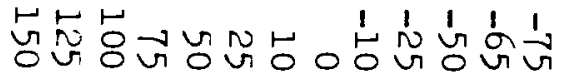

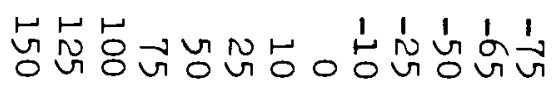

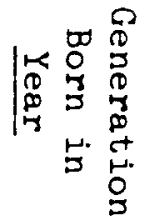

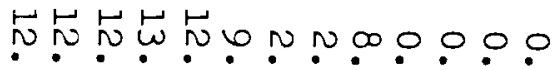

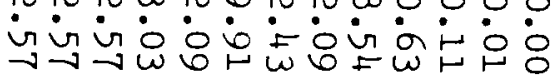

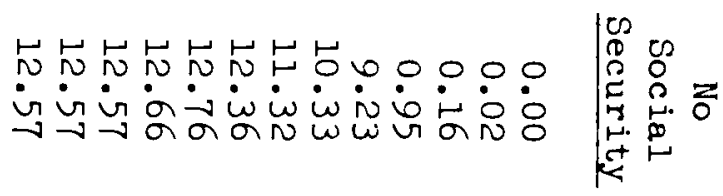

$9000045+\infty 0000$ ن்

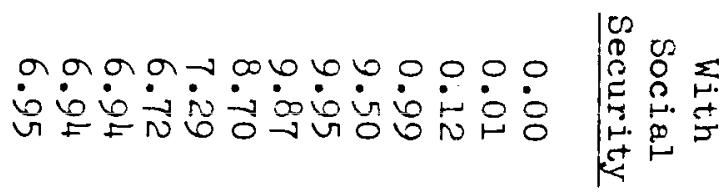

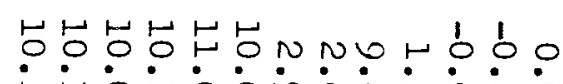

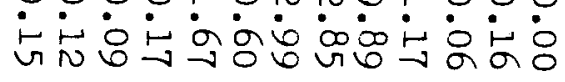

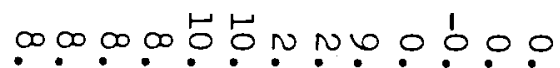

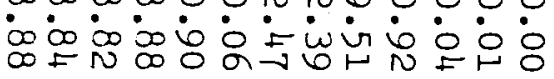

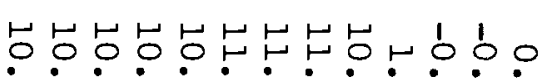
ن

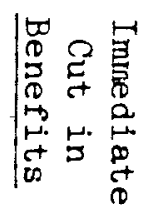

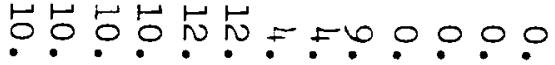

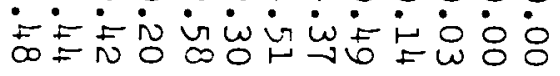

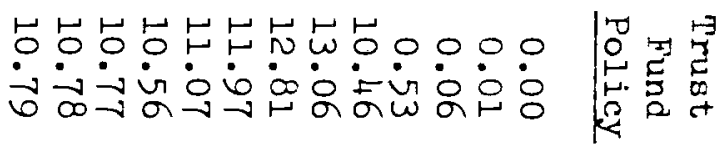

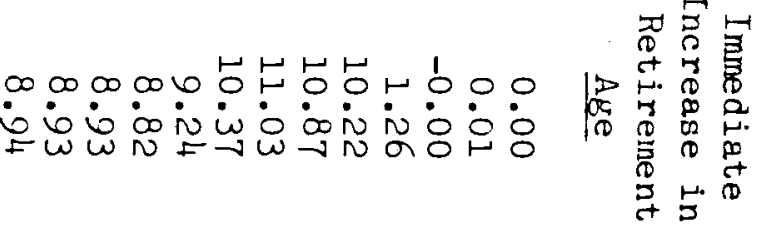

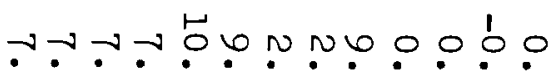

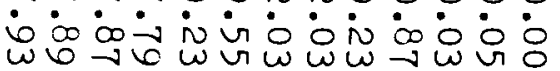


sitions considered (Table 8). At the same time, they are the only policy simulations, excluding simply passively adjusting payroll tax rates, under which each generation gains from the changes in fertility.

\section{Summary and Conclusion}

A central lesson of the simulations presented here is that demographic conditions are potentially very significant determinants of economic performance and welfare. Indeed, the time path of demographic change dominates the outcomes of each of the five social security policy transitions, despite the fact that these five simulations involve significantly different and quite substantive social security policy responses. The simulated demographic transitions suggest that the swings in U.S. fertility currently underway can have very major impacts on factor returns over the long mun and produce quite percipitious changes in saving rates in the short run. To place our findings on demographic change in perspective, it should be noted that the simulated long man changes in factor returns and capital-labor ratios from major fertility declines are of the same order of magnitude as the simulated effect of entirely abolishing unfunded social security. In comparison with the very considerable research that has been conducted concerning the saving impact of this and other government fiscal policies, the effect of demographic change on saving is a little studied phenomenon.

The presence of a social security system does have important affects on the economic transition associated with either baby busts or cycles of baby booms and busts; but the attendant financial squeeze placed on social security in these transitions is of secondary importance with respect to the long run level of economic welfare. While payroll tax rates may rise dramatically, 
long run welfare is nonetheless substantially higher, as measured in terms of equivalent increases in levels of adult consumption and leisure. This reflects, in part, the fact that each adult parent has "fewer months to feed" and, therefore, can enjoy a higher individual standard of living. In addition, while the replacement fertility rate prevailing in the long run leaves more elderly per capita in society, the sharp drop in children per capita means an overall decline in the ratio of dependents to prime age workers in the economy. For the government these changes potentially imply smaller demands on its regular fiscal operations (e.g., educational expenditures) which we model here as involving a fixed level of government consumption expenditure per capita. In our model the marginal income tax rate used to finance this spending falls from 15 percent to roughly 10.5 percent in each of the simulations in response to the lower overall dependency ratio. Hence, while the typical worker must support more elderly through social security, he (she) supports fewer children, both directly as a parent and indirectly as an income taxpayer. A glance at Tabie 3 indicates that under a passive policy of adjusting social security payroll taxes, combined income and payroll tax rates rise from an initial 20.2 percent to a long mun value of 24.2 percent. Had the income tax rate not dropped to 10.3 percent, the combined long run tax rate would have equaled 28.9 percent.

While the combined long mun tax rate is 4.2 percentage points higher in this simulation, the pre-tax waye rises by 7 percent reflecting the significant increase in capital intensity associated with the long mu decline in fertility rates. It is this general equilibrium impact on factor returns that is primarily responsible for the higher long mu level of welfare. 
Although reasonable alterations in social security policy appear incapable of significantly altering the basic economic impact of substantial demographic swings, the particular choice of social security policy is nonetheless quite important. In comparison with simply allowing payroll taxes to adjust upwards to meet required benefit payments, major reductions in replacement rates, major increases in the retirement age, or the accumulation of a significant trust fund are ali policies that can raise the long run level of welfare by an amount equivalent to almost 4 percent of lifetime expenditure on consumption and leisure. A 4 percent long run welfare increase is a large number when compared with the simulated long run welfare effects of a variety of major fiscal policy changes. The potential long mun welfare gain is not, however, freely obtained; rather, such long mun welfare gains come at the price of reductions in the welfare of transition cohorts, typically those alive at the time of the demographic change as well as those born within 25 years of the initial date of the change. Hence the choice of social security policy in the midst of the demographic transition is of considerable importance to the intergenerational distribution of welfare. 


\section{$\underline{\text { References }}$}

Auerbach, Alan and L.J. Kotlikoff. "National Savings, Economic Welfare and the Structure of Taxation," Behavioral Simulation Methods in Tax Policy Analysis. Ed.: M. Feldstein. Chicago: U. of Chicago Press, 1983a, pp. 459-93.

= "An Examination of Empirical Tests of

Social Security and Savings," Social Policy Evaluation: An Economic

Perspective. Eds.: Elhaman Helpman, et. al.: Academic Press, 1983b. - "Social Security and the Economics of

the Demographic Transition," forthcoming in Brookings Institution, Washington, D.C., 1984. , and J. Skinner. "The Efficiency Gains

from Dynamic Tax Reform." International Economic Review, February 1983c.

Kotlikoff, L. and L.H. Summers. "The Role of Intergenerational Transfers in Aggregate Capital Accumulation," J. Pol. Econ., 1981, 89(4), pp. 706-32.

Solow, R.M. "A Contribution to the Theory of Economic Growth," Q.J.E, February 1956, pp. 65-94. 